\title{
Determination of Microbiological Quality and Chlorophyll Levels Lettuce Grown Hydroponically With Wastewater
}

\author{
J. de F. Xavier ${ }^{1}$, C. A. V. de Azevedo ${ }^{1}$, M. R. de Q. A. Azevedo ${ }^{2}$, V. L. A. Lima ${ }^{1}$, J. Dantas Neto ${ }^{1}$ \\ \& S. A. dos Santos ${ }^{2}$ \\ ${ }^{1}$ Federal University of Campina Grande, Campina Grande, Paraíba, Brazil \\ ${ }^{2}$ State University of Paraíba, Campus-II, Lagoa Seca, Paraiba, Brazil \\ Correspondence: J. de F. Xavier, Federal University of Campina Grande, R. Aprígio Veloso, 882 University, \\ Campina Grande, Paraíba, Brazil. E-mail: josildaxavier@yahoo.com.br
}

Received: September 5, 2018

Accepted: October 19, 2018

Online Published: December 15, 2018

doi:10.5539/jas.v11n1p220

URL: https://doi.org/10.5539/jas.v11n1p220

The research is financed by the National Council of Scientific and Technological Development-CNPq.

\begin{abstract}
The study aimed to determine the microbiological quality for coliform in three lettuce cultivars grown hydroponically with optimized solutions. The study was conducted in a protected environment and driven in a hydroponic system adopting the technique of laminar flow nutrientes-NFT, on the premises of the State University of Paraíba-Campus II in Lagoa Seca, PB having the following coordinates: $7^{\circ} 10^{\prime} 15^{\prime \prime} \mathrm{S} ; 35^{\circ} 51^{\prime} 14^{\prime \prime} \mathrm{W}$. The experimental design was a randomized block with a split-plot treatment in $7 \times 3$ factorial, with three replicates whose factors were 7 hydroponic solutions with three lettuce cultivars. The optimized solutions were formulated taking as reference the nutrient solution Furlani. The plot was constituted by nutrient solution $(\mathrm{S}) . \mathrm{S}_{1}$ $=$ Furlani solution; $\mathrm{S}_{2}=$ domestic wastewater; $\mathrm{S}_{3}=$ optimized domestic wastewater; $\mathrm{S}_{4}=$ well water; $\mathrm{S}_{5}=$ optimized well water; $\mathrm{S}_{6}=$ wastewater from the UASB reactor and $\mathrm{S}_{7}=$ optimized wastewater from the UASB reactor and as for the subplot the three lettuce cultivars (Thais, Vanda and Veronica). In none of the samples of the three lettuce cultivars in the first experiment did the microbiological quality increase at $45^{\circ} \mathrm{C}$, by the Most Probable Number (MPN) table, when the tube combination was 0-0-0, that is, without growth in none of the tubes, it is assumed that the MPN is less than $1.8 \mu \mathrm{g}$. 11 samples were considered acceptable for the microbiological standard of thermotolerant coliforms at $45{ }^{\circ} \mathrm{C} / \mathrm{g}$. The leaf chlorophyll content is positively correlated with the $\mathrm{N}$ content in the plant.
\end{abstract}

Keywords: Lactuca sativa, reuse, nutritional solution

\section{Introduction}

The vegetables in general are essential and take a expressive part of the diet on a significant amount of the world's population. They are usually consumed "in natura" and, without washing and appropriate sanitary control, serves as transmitters of disease-causing by pathogenic microorganisms (Itohan et al., 2011).

The consumption of raw vegetables is an important means of disease transmission, as to maintain its nutritional properties.Vegetables do not undergo any heat treatment and because of that are more susceptible to the development of pathogenic microorganisms (Ramos et al., 2014).

Santos et al. (2010) studied the sanitary conditions of vegetables and irrigation water in Salvador-BA, revealed the poor condition of the surveyed areas and a large number of vegetables as well as the water used for irrigation of these, which were contaminated by fecal coliforms and E. coli.

The sanitary quality of lettuce irrigated with recycled water samples was compared with marketed in work Varallo et al. (2011). The reuse water analyzed by the authors was taken from kitchen and bathrooms of the local field trial, after that, was captured in a compound tank filter system of a septic tank followed by an anaerobic filter. Microbiological contamination may occur in lettuce before and after harvest, through contact with soil, contaminated irrigation water, and by the hands of transport handles (Constantin et al., 2013). 
The group of coliforms thermotolerant or $45{ }^{\circ} \mathrm{C}$ has been used as a source of fecal pollution indicator to be readily isolated and identified from simple and fast techniques (Silva et al., 2010). Bacteria include Gram-negative, aerobic or anaerobic, non-sporogenic and capable of fermenting lactose with gas production at $44.5^{\circ} \mathrm{C}$ or $45^{\circ} \mathrm{C}$ for 24 hours (Oliveira, 2005). Coliforms are indicators of hygienic-sanitary failures of food and preparation areas and $/ \mathrm{r}$ storage, being isolated in dairy products, meats and vegetables (Oliveira et al., 2010).

According Cova et al. (2017) who studied the cultivation of lettuce hydroponically and observed that the choice of hydroponic system and the recirculation range for lettuce crop depends on the quality of water used in the preparation of the nutrient solution. Some studies developed a technique with NFT (Nutrient Film Technique), hydroponic growing system or to an inert substrate (Santos et al., 2012) using wastewater mainly to the lettuce crop. In hydroponic nutrient absorption occurs through the roots of plants which receive a balanced nutrient solution which contains water and all nutrients essential to plant development.

The interest in using wastewater treated in irrigation it was aimed at more recent studies (Bonini et al., 2014), and became an attractive option because it reduces contamination by direct discharge of sewage into water bodies, improving the conditions of potability, allowing more rational use of water resources, being an alternative source of water available (Martinez et al., 2013).

The use of treated effluent for agricultural crops helps to control environmental pollution, as well as providing water and nutrients for crops, being a viable practice. For Ribeiro et al. (2013), the controlled discharging of the treated effluent through irrigation system aims to support the growth of crops and is dependent on factors inherent to the soil, crop, sanitary and environmental aspects.

The use of treated wastewater can be a source of water and nutrients available for use in agriculture, even during periods of drought (Shaer Barbosa et al., 2014). On the other hand, the safety of reuse of these wastewaters for irrigation purposes is cause for caution. To Ayers and Westcot (1999), the use of wastewater in agriculture, should be taken into account the physical, chemical and biological characteristics of the water, that are reflected in the productivity and quality of crops, soil fertility maintenance and protection of man and the environment.

The determination of the relative chlorophyll content (or content SPAD) through the portable chlorophyll meter (chlorophyll meter) is being used to predict the need for nitrogen fertilization in various crops, adding advantages such as simplicity of use and the possibility of non-destructive evaluation of the fabric leaf (Argenta et al., 2001). Another advantage of measuring the chlorophyll content is not influenced by the luxury consumer $\mathrm{C}$ the plant, since, when absorbed in excess, $\mathrm{N}$ accumulates in the form of nitrate and is not associated with the chlorophyll molecule, not being detected by chlorophyll meter (Dwyer et al., 1995). To determine the leaves chlorophyll content can be used to infer the nutritional quality of the plant because the chlorophyll concentration is directly related to the nitrogen content in the plant tissues (Argenta et al., 2001). Thus, the chlorophyll concentration can be used as an indicator of the lack of plant nutrients. Traditional methods chlorophyll extraction require a high cost of labor, goods and there is the destruction of plant tissue. Recently it developed a portable indirect meter of chlorophyll great precision, known as Minolta SPAD-502 (Soil Plant Analysis Development). The operation of this equipment is based on quantification of light transmitted through a sheet at two wavelengths with different chlorophyll absorbance values (Minolta, 1989).

This study aimed to determine the microbiological quality for coliform and chlorophyll levels in three lettuce cultivars grown hydroponically with optimized solutions with wastewater.

\section{Material and Methods}

\subsection{Experimental Area Location}

The study was conducted in a protected environment and driven in a hydroponic system adopting the technique of the laminar flow of nutrients (NFT) in the facilities of the State University of Paraíba-UEPB campus II in Lagoa Seca PB having the following coordinates: $7^{\circ} 10^{\prime} 15^{\prime \prime} \mathrm{S}$; $35^{\circ} 51^{\prime} 14^{\prime \prime} \mathrm{W}$ at an altitude of 634 meters, climate characterized as tropical humid (s'), with an average annual temperature around $22{ }^{\circ} \mathrm{C}$, minimum $18{ }^{\circ} \mathrm{C}$ and maximum $33^{\circ} \mathrm{C}$ according to the climate classification Koppen adapted to Brazil (1971). Two experiments were conducted in the period 14 April to September 2016.

\subsection{Experiment Installation and Conducting}

The experimental design was a randomized block with a split-plot treatment in $7 \times 3$ factorial, with three replicates whose factors were 7 hydroponic solutions with a conductivity of $1.7 \mathrm{dS} \mathrm{m}^{-1}$ and three lettuce cultivars. The optimized solutions were formulated taking as reference the nutrient solution Furlani (1995). The plot was constituted by nutrient solution ( $\mathrm{S}$ ). $\mathrm{S}_{1}=$ Furlani solution; $\mathrm{S}_{2}=$ domestic wastewater (raw sewage); $\mathrm{S}_{3}=$ optimized domestic wastewater (raw sewage); $\mathrm{S}_{4}=$ well water saline; $=\mathrm{S}_{5}$ optimized well water saline; $\mathrm{S}_{6}=$ 
wastewater from the UASB reactor and $\mathrm{S}_{7}=$ optimized wastewater from the UASB reactor and as for the subplot the three lettuce cultivars (Veronica, and Vanda Thais), each sub plot was composed of six plants with spacing of $0.30 \mathrm{~m} \times 0.3 \mathrm{~m}$.

The number of mineral fertilizers and chemical composition of the mineral nutrient solution are shown in Tables 1 and 2 for this, we used the Solver tool Microsoft Office Excel; All solutions were prepared for $200 \mathrm{~L}$.

Table 1. Quantity of mineral fertilizers used in the manufacture of mineral nutrient solutions

\begin{tabular}{ll}
\hline Solution & Furlani \\
\hline Mineral salts & 1000 \\
\hline$-\mathrm{Ca}\left(\mathrm{NO}_{3}\right)_{2} \cdot 6 \mathrm{H}_{2} \mathrm{O}$ : Calcium nitrate & 150 \\
$\mathrm{MAP}:$ Monoammonium phosphate & - \\
DAP: Diammonium phosphate & - \\
$\mathrm{H}_{2} \mathrm{PO}_{4}:$ Phosphoric acid & - \\
$\mathrm{KH}_{2} \mathrm{PO}_{4}:$ Phosphate monopotassium & 150 \\
$\mathrm{KCl}$ Potassium chloride & 600 \\
$\mathrm{KNO}_{3}:$ Potassium nitrate & 250 \\
$\mathrm{MgSO}_{4} \cdot 7 \mathrm{H}_{2} \mathrm{O}:$ Magnesium sulfate & 2.34 \\
$\mathrm{MnCl}_{2}: \mathrm{H}_{2}:$ Manganese chloride & - \\
$\mathrm{MnSO}_{4} \cdot \mathrm{H}_{2} \mathrm{O}:$ Manganese sulfate & 0.88 \\
$\mathrm{ZnSO}_{4} \cdot 7 \mathrm{H}_{2} \mathrm{O}:$ Zinc sulfate & 0.2 \\
$\mathrm{CuSO}_{4} \cdot 7 \mathrm{H}_{2} \mathrm{O}:$ Copper sulfate & 2.04 \\
$\mathrm{H}_{3} \mathrm{BO}_{3}:$ Boric acid & 0.26 \\
$\mathrm{Na}_{2} \mathrm{MoO}_{4} \cdot 2 \mathrm{H}_{2} \mathrm{O}:$ Ammonium molybdate & $1000 \mathrm{~mL}$ \\
$\mathrm{Fe}_{-}-\mathrm{EDTA}:$ Iron Ethylenediamine tetraacetic acid & \\
\hline
\end{tabular}

Table 2. Chemical composition of mineral nutritive solutions

\begin{tabular}{lc}
\hline Solution & \\
\hline Mineral Salts & Furlani \\
\hline$--\mathrm{NO}_{3}$ : Nitrate & 200.44 \\
$\mathrm{NH}_{4}$ : Ammonium & 16.51432 \\
$\mathrm{P}$ : Phosphor & 32.7 \\
$\mathrm{~K}:$ Potassium & 310.275 \\
$\mathrm{Ca}:$ Calcium & 168 \\
$\mathrm{Mg}:$ Magnesium & 24.65 \\
$\mathrm{~S}:$ Sulfur & 32.5 \\
$\mathrm{Mn}:$ Manganese & 0.636714 \\
$\mathrm{Zn}:$ Zinc & 0.199144 \\
$\mathrm{Cu}:$ Copper & 0.0671 \\
Bo: Boron & 0.356592 \\
$\mathrm{Mo}:$ Molybdenum & 0.114452 \\
Fe: Iron & 2.234 \\
\hline
\end{tabular}

The water used in the experiment came from rainwater stored that was captured in cisterns (solution $\mathrm{S}_{1}$ ), raw sewage from the city of Lagoa Seca-PB, tubular well water from the rural area of the municipality of Lagoa Seca-PB and from wastewater of the UASB reactor of the Experimental Station of Biological Treatment of Sanitary Sewers (Extrabes) Campina Grande-PB. The physicochemical analyzes of the waters used in the experiments (Table 3) were performed in the Laboratory of Irrigation and Salinity (LIS/DEAg/UFCG). 
Table 3. Physical-chemical characterization of the water used in the irrigation of three cultivars of lettuce in a hydroponic system

\begin{tabular}{|c|c|c|c|c|c|c|}
\hline \multirow[b]{2}{*}{ Determinations } & \multicolumn{3}{|c|}{ First Experiment } & \multicolumn{3}{|c|}{ Second Experiment } \\
\hline & $\begin{array}{l}\text { Saline } \\
\text { Well water }\end{array}$ & $\begin{array}{l}\text { domestic } \\
\text { wastewater } \\
\text { (raw sewage) }\end{array}$ & $\begin{array}{l}\text { Water from } \\
\text { the UASB } \\
\text { reactor }\end{array}$ & $\begin{array}{l}\text { Saline } \\
\text { Well water }\end{array}$ & $\begin{array}{l}\text { domestic } \\
\text { wastewater } \\
\text { (raw sewage) }\end{array}$ & $\begin{array}{l}\text { Water from } \\
\text { the UASB } \\
\text { reactor }\end{array}$ \\
\hline $\mathrm{pH}=$ hydrogen potential & 7.7 & 7.4 & 7.2 & 7.4 & 8.0 & 8.2 \\
\hline CE-Electric condu-ctivity $\left(\mathrm{dS} \mathrm{m}^{-1}\right)$ & 0.957 & 2.133 & 2.502 & 1.002 & 2.368 & 2.409 \\
\hline Calcium $\left(\mathrm{mmol}_{\mathrm{c}} / \mathrm{L}\right)$ & 3.62 & 3.98 & 5.98 & 1.98 & 4.55 & 2.40 \\
\hline Magnesium $\left(\mathrm{mmol}_{\mathrm{d}} / \mathrm{L}\right)$ & 0.75 & 3.47 & 3.42 & 1.88 & 2.25 & 4.60 \\
\hline Sodium $\left(\mathrm{mmol}_{\mathrm{c}} / \mathrm{L}\right)$ & 3.94 & 10.57 & 15.55 & 4.69 & 12.32 & 13.48 \\
\hline Potassium $\left(\mathrm{mmol}_{\mathrm{c}} / \mathrm{L}\right)$ & 0.38 & 1.26 & 0.01 & 0.41 & 1.39 & 0.89 \\
\hline Chlorides $\left(\mathrm{mmol}_{\mathrm{c}} / \mathrm{L}\right)$ & 6.42 & 9.99 & 23.23 & 6.43 & 9.28 & 12.76 \\
\hline Carbonates $\left(\mathrm{mmol}_{\mathrm{c}} / \mathrm{L}\right)$ & 0.00 & 0.00 & 0.00 & 0.00 & 0.00 & 0.00 \\
\hline Bicarbonate $\left(\mathrm{mmol}_{\mathrm{c}} / \mathrm{L}\right)$ & 1.31 & 10.95 & 3.25 & 1.26 & 13.98 & 9.66 \\
\hline Total phosphorus $\left(\mathrm{mgL}^{-1}\right)$ & 4.51 & 29.30 & 4.14 & 1.83 & 19.02 & 13.41 \\
\hline Nitrate $\left(\mathrm{NO}_{3}^{-}\right)\left(\mathrm{mg} \mathrm{L}^{-1}\right)$ & 16.73 & 0.00 & 1.03 & 15.23 & 0.00 & 0.00 \\
\hline Ammonia $\left(\mathrm{NH}_{3}\right)\left(\mathrm{mg} \mathrm{L}^{-1}\right)$ & 0.61 & 1.27 & 58.6 & 0.11 & 1.19 & 52.46 \\
\hline Sodium adsorption ratio (RAS) & 2.57 & 6.93 & 8.53 & 3.02 & 9.59 & 8.15 \\
\hline Water class for irrigation & $\mathrm{C}_{2} \mathrm{~S}_{1} \mathrm{~T}_{2}$ & $\mathrm{C}_{3} \mathrm{~S}_{1} \mathrm{~T}_{3}$ & $\mathrm{C}_{3} \mathrm{~S}_{1} \mathrm{~T}_{3}$ & $\mathrm{C}_{2} \mathrm{~S}_{2} \mathrm{~T}_{2}$ & $\mathrm{C}_{3} \mathrm{~S}_{1} \mathrm{~T}_{3}$ & $\mathrm{C}_{3} \mathrm{~S}_{1} \mathrm{~T}_{3}$ \\
\hline
\end{tabular}

The nutrient solutions $S_{3}, S_{5}$ and $S_{7}$ were prepared according to the methodology proposed by Furlani (1995). Once formulated, the organic ingredients were mixed, when necessary, with mineral fertilizers, in order to present chemical composition similar to that of the Furlani solution (Table 4). During the experiment, $\mathrm{S}_{1}$ solution and the remaining optimized solutions were calibrated by means of electric conductivity (EC) and hydrogen potential $(\mathrm{pH})$ reading, using a portable conductivity meter in addition to a peg; the $\mathrm{EC}$ was maintained at approximately $1.7 \pm 0.3 \mathrm{dS} \mathrm{cm}^{-1}$ and the $\mathrm{pH}$ between 6.0 and 7.0 ; regardless of treatments, the nutrient solutions were changed in equidistant periods of 7 days.

Table 4. Quantitative of the ingredients used in the preparation of the solutions $\mathrm{S}_{3}=$ optimized domestic waste water; $\mathrm{S}_{5}=$ Optimized saline well water and $\mathrm{S}_{7}=$ optimized wastewater from the UASB reactor from the physicochemical characterization of waters used in hydroponic irrigation

\begin{tabular}{llll}
\hline \multirow{2}{*}{ Ingredients } & \multicolumn{2}{c}{ Quantity of ingredients used to prepare optimized solutions } \\
\cline { 2 - 4 } & $\mathrm{S}_{3}$ & $\mathrm{~S}_{5}$ & $\mathrm{~S}_{7}$ \\
\hline Optimized domestic waste water (raw sewage) & $199.58 \mathrm{~L}$ & - & - \\
Optimized well salt water & - & $199.64 \mathrm{~L}$ & - \\
Optimized wastewater from the UASB reactor & - & - & $199.64 \mathrm{~L}$ \\
Ammonium sulfate $\left[\left(\mathrm{NH}_{4}\right)_{2} \mathrm{SO}_{4}\right]$ & $23.66 \mathrm{~g}$ & $22.31 \mathrm{~g}$ & $25.09 \mathrm{~g}$ \\
Calcium nitrate $\left[\left(\mathrm{NO}_{3}\right)_{2}\right]$ & $238.24 \mathrm{~g}$ & $237.53 \mathrm{~g}$ & $193.54 \mathrm{~g}$ \\
Potassium nitrate $\left(\mathrm{KNO}_{3}\right)$ & $84.06 \mathrm{~g}$ & $80.95 \mathrm{~g}$ & $121.74 \mathrm{~g}$ \\
Potassium chloride $\left(\mathrm{KCl}^{2}\right.$ & $46.32 \mathrm{~g}$ & $50.04 \mathrm{~g}$ & $0.00 \mathrm{~g}$ \\
Copper Sulfate $\left(\mathrm{CuSO}_{4}\right)$ & $0.04 \mathrm{~g}$ & $0.04 \mathrm{~g}$ & $0.04 \mathrm{~g}$ \\
Zinc sulfate $\left(\mathrm{ZnSO}_{4}\right)$ & $0.11 \mathrm{~g}$ & $0.11 \mathrm{~g}$ & $0.11 \mathrm{~g}$ \\
Manganese $\mathrm{Sulfate}\left(\mathrm{MnSo}_{4}\right)$ & $0.49 \mathrm{~g}$ & $0.49 \mathrm{~g}$ & $0.49 \mathrm{~g}$ \\
Magnesium sulphate $\left(\mathrm{MgSO}_{4}\right)$ & $2.19 \mathrm{~g}$ & $4.27 \mathrm{~g}$ & $0.00 \mathrm{~g}$ \\
Ammonium molybdate $\left[\left(\mathrm{NH}_{4}\right)_{6} \mathrm{Mo}_{7} \mathrm{O}_{24}\right]$ & $0.06 \mathrm{~g}$ & $0.06 \mathrm{~g}$ & $0.06 \mathrm{~g}$ \\
Boric acid $\left(\mathrm{H}_{3} \mathrm{BO}_{3}\right)$ & $0.42 \mathrm{~g}$ & $0.42 \mathrm{~g}$ & $0.42 \mathrm{~g}$ \\
Monoammonium phosphate $(\mathrm{MAP})$ & $3.14 \mathrm{~g}$ & $10.43 \mathrm{~g}$ & $5.14 \mathrm{~g}$ \\
Iron sulphate $\left(\mathrm{FeSO}_{4}\right)$ & $12.05 \mathrm{~g}$ & $12.05 \mathrm{~g}$ & $12.05 \mathrm{~g}$ \\
\hline
\end{tabular}


The management of the nutritive solutions were performed daily through the replenishment of the water consumed, along with the monitoring of the electrical conductivity (EC) and $\mathrm{pH}$ keeping it close to neutrality, with the use of a solution of $\mathrm{NaOH}$ ou HCL $\left(1 \mathrm{~mol} \mathrm{~L}^{-1}\right)$. Monoammonium phosphate (MAP).

\subsection{Evaluated Characteristics}

In the treatments of lettuce cultivars were evaluated at 30 days after transplanting for the following parameters: total coliforms $\left(35^{\circ} \mathrm{C}\right)$, thermophilic $\left(45^{\circ} \mathrm{C}\right)$ and chlorophyll levels.

To determine the microbiological quality was adopted official method approved by the Association of Official Analytical Chemists-AOAC (2002) for coliforms at $35{ }^{\circ} \mathrm{C}$ thermotolerant at $45{ }^{\circ} \mathrm{C}$ using the technique of multiple tubes chlorophyll levels were determined by using the portable chlorophyll meter SPAD-502 [Soil-Plant Analysis Development (SPAD)] section. Camer Minolta Co., Ltd., Japan.

To carry out microbiological analyzes adopted is the following: it was harvested at random a sample formed by six plants/plot plant tissue in nature cultivars (Thaís, Veronica and Vanda) in the treatments and replicates.

To prevent the contamination, was cut the shoot at the base of the plant and leaving the roots in the system. The material used for the collection were surgical gloves and a knife. Each knife collection was sterilized with $70 \%$ alcohol and then the plant tissue was properly packaged in a zipped plastic bag and sent to be analyzed in the Food Microbiology Laboratory of the State University of Paraíba Center of Agrarian and Environmental Sciences UEPB-CAES, Campus II.

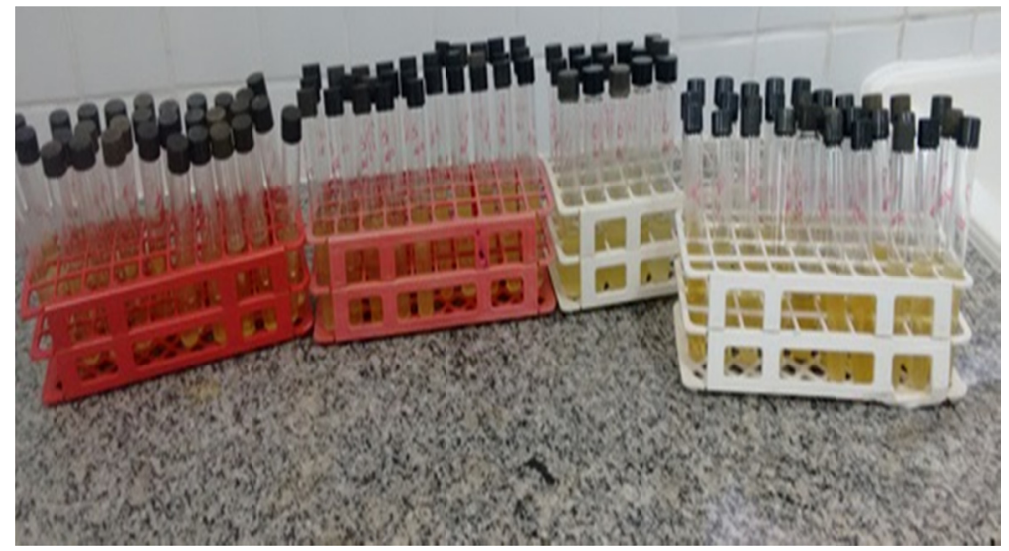

Figure 1. Preparation tubes for reading the estimated number of fecal coliform the most probable number method (MPN)

\subsection{Statistical Analysis}

Data were subjected to analysis of variance by $\mathrm{F}$ test for 1 and $5 \%$ probability. When a significant effect was observed on analysis of variance, the mean values obtained in the different treatment means were compared by Tukey's test to 5\% probability SISVAR using statistical software (Ferreira, 2014).

\section{Results and Discussion}

\subsection{Total Coliforms and Three Lettuce Cultivars Were Grown Under Different Optimized Solutions}

The sanitary microbiological standard for fresh produce is characterized for coliforms at $45^{\circ} \mathrm{C} / \mathrm{g}$. The analysis of the microbiological quality of the three cultivars of lettuce as in the first experiment can be seen in Table 5 in the samples was no growth at $45^{\circ} \mathrm{C}$, by Most Probable Number table (MPN), when the combination of the tubes is $0-0-0$, or no growth on any of the tubes, it is assumed that the MPN is less than $1.8 / \mathrm{g}$. For this result, all samples are regarded as acceptable for microbiological standard thermotolerant coliforms at $45^{\circ} \mathrm{C} / \mathrm{g}$.

The presence of coliforms in vegetables is of concern since it is consumed raw. thermotolerant coliform bacteria are indicators of fecal contamination, which confirmed the presence of E. coli. The presence of this microorganism contamination comes from homeothermic animal feces or domestic sewage and therefore may be indicating the presence of pathogenic microorganisms to food and water stream which can cause serious infectious diseases such as cholera, salmonellosis, shigelloses and hepatitis, among others. 
Table 5. Microbiological quality of the first experiment of lettuce cultivars subjected to different treatments

\begin{tabular}{|c|c|c|c|c|c|c|}
\hline \multirow{3}{*}{ Sample } & \multicolumn{3}{|c|}{ Total coliforms $\left(35^{\circ} \mathrm{C}\right)$} & \multicolumn{3}{|c|}{ Coliforms $\left(45^{\circ} \mathrm{C}\right)$} \\
\hline & \multirow{2}{*}{ MLN/g } & \multicolumn{2}{|c|}{ Confidence Interva } & \multirow{2}{*}{ MLN/g } & \multicolumn{2}{|c|}{ Confidence Interva } \\
\hline & & Minimum & Maximum & & Minimum & Maximum \\
\hline $\mathrm{B}_{1} \mathrm{~S}_{1}$ & $>1.8$ & - & 6.8 & $>1.8$ & - & 6.8 \\
\hline $\mathrm{B}_{1} \mathrm{~S}_{2}$ & 23 & 6.8 & 70 & $>1.8$ & - & 6.8 \\
\hline $\mathrm{B}_{1} \mathrm{~S}_{3}$ & $>1.8$ & - & 6.8 & $>1.8$ & - & 6.8 \\
\hline $\mathrm{B}_{1} \mathrm{~S}_{4}$ & $>1.8$ & - & 6.8 & $>1.8$ & - & 6.8 \\
\hline $\mathrm{B}_{1} \mathrm{~S}_{5}$ & $>1.8$ & - & 6.8 & $>1.8$ & - & 6.8 \\
\hline $\mathrm{B}_{1} \mathrm{~S}_{6}$ & 26 & 9.8 & 70 & $>1.8$ & - & 6.8 \\
\hline $\mathrm{B}_{1} \mathrm{~S}_{7}$ & 9.2 & 3.4 & 22 & $>1.8$ & - & 6.8 \\
\hline $\mathrm{B}_{2} \mathrm{~S}_{1}$ & $>1.8$ & - & 6.8 & $>1.8$ & - & 6.8 \\
\hline $\mathrm{B}_{2} \mathrm{~S}_{2}$ & 6.1 & 1.8 & 15 & $>1.8$ & - & 6.8 \\
\hline $\mathrm{B}_{2} \mathrm{~S}_{3}$ & $>1.8$ & - & 6.8 & $>1.8$ & - & 6.8 \\
\hline $\mathrm{B}_{2} \mathrm{~S}_{4}$ & 9.2 & 3.4 & 22 & $>1.8$ & - & 6.8 \\
\hline $\mathrm{B}_{2} \mathrm{~S}_{5}$ & 4.5 & 0.79 & 15 & $>1.8$ & - & 6.8 \\
\hline $\mathrm{B}_{2} \mathrm{~S}_{6}$ & 12 & 4.1 & 26 & $>1.8$ & - & 6.8 \\
\hline $\mathrm{B}_{2} \mathrm{~S}_{7}$ & 14 & 5.6 & 36 & $>1.8$ & - & 6.8 \\
\hline $\mathrm{B}_{3} \mathrm{~S}_{1}$ & $>1.8$ & - & 6.8 & $>1.8$ & - & 6.8 \\
\hline $\mathrm{B}_{3} \mathrm{~S}_{2}$ & 6.1 & 1.8 & 15 & $>1.8$ & - & 6.8 \\
\hline $\mathrm{B}_{3} \mathrm{~S}_{3}$ & 2 & 0.1 & 10 & $>1.8$ & - & 6.8 \\
\hline $\mathrm{B}_{3} \mathrm{~S}_{4}$ & 14 & 5.6 & 36 & $>1.8$ & - & 6.8 \\
\hline $\mathrm{B}_{3} \mathrm{~S}_{5}$ & 9.2 & 3.4 & 22 & $>1.8$ & - & 6.8 \\
\hline $\mathrm{B}_{3} \mathrm{~S}_{6}$ & 12 & 4.1 & 26 & $>1.8$ & - & 6.8 \\
\hline $\mathrm{B}_{3} \mathrm{~S}_{7}$ & 12 & 5.1 & 36 & $>1.8$ & - & 6.8 \\
\hline
\end{tabular}

Note. $\mathrm{B}=$ block, $\mathrm{MLN}=$ Most Likely Number. $\mathrm{S}_{1}=$ Furlani solution; $\mathrm{S}_{2}=$ domestic wastewater (raw sewage); $\mathrm{S}_{3}$ $=$ optimized domestic wastewater (raw sewage); $\mathrm{S}_{4}=$ well water saline; $\mathrm{S}_{5}=$ optimized well water saline; $\mathrm{S}_{6}=$ wastewater from the UASB reactor and $\mathrm{S}_{7}=$ optimized wastewater from the UASB reactor.

The coliform values found at $45^{\circ} \mathrm{C}$ in nutrient solutions, as well as in the water reservoir used in the preparation of the solutions is below the value set by resolution 357/2005 (CONAMA, 2005) which is $200 \mathrm{NMP} 100 \mathrm{~mL}^{-1}$. This fact contributed to the low count of coliform thermotolerant found in lettuce samples evaluated. According to Brazilian law, the limit for the presence of $45{ }^{\circ} \mathrm{C}$ coliforms in vegetables, vegetables and similar fresh in natura prepared (stripped selected or fractionated) sanitized, refrigerated or frozen for direct consumption is 102 MPN/g (Brazil, 2001).

Studies have shown that in hydroponic cultures of microbial contamination is lowest, according to Tonet et al. (2011) evaluated the cultivation of lettuce hydroponically and aquaponic showed that, despite the existence of fecal coliform in the water used in the production process, the results met in consumption patterns stipulated by law.

Monteiro Filho (2015) in his research that the same cultivars studied in this research found that, regardless of the solution used, the curled lettuce samples analyzed show no contamination for the presence of $E$. coli and Salmonella, with these results the risk on consumer health by eating lettuce contamination decrease gradually. Tavella et al. (2012) observed with applications of biofertilizer with dilution greater than $3 \%$, foliar, a high contamination levels for total coliforms ( $460 \mathrm{MPN} \mathrm{g}^{-1}$ ). Similar results were also obtained by Arbos et al. (2010) evaluating lettuce fertilized with organic fertilizer, the contamination found above ( $240 \mathrm{MPN} \mathrm{g}^{-1}$ ); Baumgartner et al. (2007) using recycled water fish breeding swine and applied via the drip (2400 NMP g$\left.{ }^{-1}\right)$.

It can be seen in Table 6 that none of the samples in which growth was at $45^{\circ} \mathrm{C}$ in Table Most Probable Number (MPN), when the combination of the tubes is $0-0-0$, ie no growth on any of the tubes, MPN is presumed that is less than 1.8/g. For this result, all samples are regarded as acceptable for the microbiological standard of coliforms at $45^{\circ} \mathrm{C} / \mathrm{g}$. 
Table 6. Microbiological quality of the second experiment lettuce cultivars subjected to different treatments

\begin{tabular}{|c|c|c|c|c|c|c|}
\hline \multirow{3}{*}{ Sample } & \multicolumn{3}{|c|}{ Total coliforms $\left(35^{\circ} \mathrm{C}\right)$} & \multicolumn{3}{|c|}{ Coliforms $\left(45^{\circ} \mathrm{C}\right)$} \\
\hline & \multirow{2}{*}{$\mathrm{MLN} / \mathrm{g}$} & \multicolumn{2}{|c|}{ Confidence Interva } & \multirow{2}{*}{$\mathrm{MLN} / \mathrm{g}$} & \multicolumn{2}{|c|}{ Confidence Interva } \\
\hline & & Minimum & Maximum & & Minimum & Maximum \\
\hline $\mathrm{B}_{1} \mathrm{~S}_{1}$ & $>1.600$ & 700 & - & $<1.8$ & - & 6.8 \\
\hline $\mathrm{B}_{1} \mathrm{~S}_{2}$ & 1.8 & 0.09 & 6.8 & $<1.8$ & - & 6.8 \\
\hline $\mathrm{B}_{1} \mathrm{~S}_{3}$ & 2 & 0.1 & 10 & $<1.8$ & - & 6.8 \\
\hline $\mathrm{B}_{1} \mathrm{~S}_{4}$ & 4 & 0.7 & 12 & $<1.8$ & - & 6.8 \\
\hline $\mathrm{B}_{1} \mathrm{~S}_{5}$ & 180 & 70 & 400 & $<1.8$ & - & 6.8 \\
\hline $\mathrm{B}_{1} \mathrm{~S}_{6}$ & 1.8 & 0.09 & 6.9 & $<1.8$ & - & 6.8 \\
\hline $\mathrm{B}_{1} \mathrm{~S}_{7}$ & 4 & 0.7 & 12 & $<1.8$ & - & 6.8 \\
\hline $\mathrm{B}_{2} \mathrm{~S}_{1}$ & 9.3 & 3.4 & 22 & $<1.8$ & - & 6.8 \\
\hline $\mathrm{B}_{2} \mathrm{~S}_{2}$ & $<1.8$ & - & 6,8 & $<1.8$ & - & 6.8 \\
\hline $\mathrm{B}_{2} \mathrm{~S}_{3}$ & 14 & 5.9 & 36 & $<1.8$ & - & 6.8 \\
\hline $\mathrm{B}_{2} \mathrm{~S}_{4}$ & 17 & 6.8 & 40 & $<1.8$ & - & 6.8 \\
\hline $\mathrm{B}_{2} \mathrm{~S}_{5}$ & 1.8 & 0.009 & 6.8 & $<1.8$ & - & 6.8 \\
\hline $\mathrm{B}_{2} \mathrm{~S}_{6}$ & 4.5 & 0.79 & 15 & $<1.8$ & - & 6.8 \\
\hline $\mathrm{B}_{2} \mathrm{~S}_{7}$ & 2 & 0.1 & 10 & $<1.8$ & - & 6.8 \\
\hline $\mathrm{B}_{3} \mathrm{~S}_{1}$ & 2 & 0.1 & 10 & $<1.8$ & - & 6.8 \\
\hline $\mathrm{B}_{3} \mathrm{~S}_{2}$ & 24 & 9.8 & 70 & $<1.8$ & - & 6.8 \\
\hline $\mathrm{B}_{3} \mathrm{~S}_{3}$ & $<1.8$ & - & 6.8 & $<1.8$ & - & 6.8 \\
\hline $\mathrm{B}_{3} \mathrm{~S}_{4}$ & 4 & 0.7 & 10 & $<1.8$ & - & 6.8 \\
\hline $\mathrm{B}_{3} \mathrm{~S}_{5}$ & 4 & 0.7 & 12 & $<1.8$ & - & 6.8 \\
\hline $\mathrm{B}_{3} \mathrm{~S}_{6}$ & 4 & 0.7 & 12 & $<1.8$ & - & 6.8 \\
\hline $\mathrm{B}_{3} \mathrm{~S}_{7}$ & $<1.8$ & - & 6.8 & $<1.8$ & - & 6.8 \\
\hline
\end{tabular}

Note. $\mathrm{B}=$ block, $\mathrm{MLN}=$ Most Likely Number. $\mathrm{S}_{1}=$ Furlani solution; $\mathrm{S}_{2}=$ domestic wastewater (raw sewage); $\mathrm{S}_{3}$ $=$ optimized domestic wastewater (raw sewage); $\mathrm{S}_{4}=$ well water saline; $\mathrm{S}_{5}=$ optimized well water saline; $\mathrm{S}_{6}=$ wastewater from the UASB reactor and $\mathrm{S}_{7}=$ optimized wastewater from the UASB reactor.

The low contamination values for total coliforms found in lettuce samples (Table 6) indicate that the hydroponic system may be efficient as the smaller microbial contamination of the cultures produced in this system according to the nutrient solutions did not come into contact with the shoot culture as frequently occurs in conventional organic or production systems. Clearly, the mode of application of irrigation water and fertilizer has great significance in the process of contamination of vegetables. Santos et al. (2010) analyzing hydroponic lettuce samples taken from the commerce of the city of Botucatu, SP, found contamination by fecal coliforms NMP de $4.6 \times 10^{4}$. Although the contamination of the hydroponic system from lettuce is related to post-harvest, there are cases reported, as the Tonet et al. (2011) who found in lettuce harvested in the hydroponic system, contamination of greater than $1100 \mathrm{~g}^{-1}$ MPN in $30 \%$ of the samples.

As the occurrence of thermotolerant coliform $\left(45^{\circ} \mathrm{C}\right)$, the values found in curly lettuce cultivars ranged from 1.8 to 6.8 MPN g ${ }^{-1}$ (Table 6). These results are considered satisfactory as the National Health Agency down for fresh vegetables "in natura", the default maximum presence of $100 \mathrm{MPNg}^{-1}$ (ANVISA, 2001). Monteiro Filho (2015) analyzed the samples of curly lettuce in their research and found that they possess no contamination for the presence of E. coli and Salmonella. Rios (2008) studied the use of yellow water (human urine) with contamination by fecal coliforms above $1100 \mathrm{NMP} 100 \mathrm{~mL}^{-1}$ in hydroponics of lettuce, also harvested plants within acceptable standards for consumption. These results corroborate with those found in this study.

The presence of thermotolerant coliforms in vegetables is of concern since it is consumed raw. thermotolerant coliform bacteria are indicators of fecal contamination, which is confirmed by the presence of $E$. coli. The presence of this microorganism contamination comes from homeothermic animal feces or domestic sewage and therefore may be indicating the presence of pathogenic microorganisms to food and water stream, which can cause serious infectious diseases such as cholera, salmonellosis, shigelloses and hepatitis, among others.

The results obtained by Santos (2014) showed that the number average determined from the MPN technique for coliforms at $45^{\circ} \mathrm{C}$ ranged from $<3.0$ to $9.2 \times 106 \mathrm{NMP} / 100 \mathrm{~g}$. From the statistical verification, it was found that 
salad mayonnaise differs significantly from composite and lettuce salads, which had a high contamination by coliforms at $45^{\circ} \mathrm{C}$.

\subsection{Chlorophyll Levels Obtained by the Method (SPAD-502) in Three Lettuce Cultivars}

It can be seen in Table 7 that the results of the chlorophyll levels of leaves of lettuce cultivars analyzed by an indirect index of SPAD at $(\mathrm{cm})$ in the first experiment, the nutrient solution factor $(\mathrm{S})$ had significantly influence on the level of $1 \%$ probability $(p<0.01)$. In Table 7 we observe that in the second experiment, the nutrient solution factor $(\mathrm{S})$ had significantly influence on the level of $5 \%$ probability $(0.01 \leq \mathrm{p}<0.05)$ for analysis of chlorophyll.

Table 7. Analysis of variance of chlorophyll in the first and second experiment evaluated in the field by the SPAD index $(\mathrm{cm})$ in the three hydroponics of lettuce cultivars subjected to different treatment first experiment

\begin{tabular}{llll}
\hline Middle Squere $(\mathrm{Ms})$ & & & \\
\hline Source of variation & DF & SPAD $\left(1^{\circ}\right.$ experiment $)$ & SPAD $\left(2^{\circ}\right.$ experiment $)$ \\
\hline Solution (S) & 6 & $59.51^{* *}$ & $3.5857^{*}$ \\
Block & 2 & $18.02^{\mathrm{ns}}$ & $0.06^{\mathrm{ns}}$ \\
Resídue of parcel & 12 & 8.56 & 6.27 \\
Cultivar (C) & 2 & $5.15^{\mathrm{ns}}$ & $5.30^{*}$ \\
Cultivar $\times$ Solution & 12 & $0.77^{\mathrm{ns}}$ & $3.51^{* *}$ \\
Resídue of the subplot & 26 & 1.59 & 12.92 \\
CV 1 & & 13.81 & 13.33 \\
CV 2 & & 5.96 & 19.14 \\
Overall average & & 21.19 & 18.78 \\
\hline
\end{tabular}

Note. SPAD: Soil-Plant Analysis Development; DF: degree of freedom; ${ }^{\text {ns }}$ not significant; ${ }^{* *}$ significant at the level of $1 \%$ probability $(\mathrm{p}<0.01)$; $^{*}$ significant at a $5 \%$ probability level $(0.01 \leq \mathrm{p}<0.05)$ by the $\mathrm{F}$ test; $\mathrm{CV}=$ coefficient of variance.

For isolated made cultivars (C) is observed in Table 7, there was no significant effect of chlorophyll analyzed by an indirect index of the SPAD (cm) in the first experiment. In the second experiment is observed in Table 7, there was a significant influence on the level of $5 \%$ probability $(0.01 \leq p<0.05)$. As for the interaction between nutrient solution (S) and cultivars $(\mathrm{C})$, it was observed that there was no significant effect on chlorophyll analyzed by indirect index of SPAD at $(\mathrm{cm})$ in the first experiment, while in the second experiment, the significant effect was $5 \%$ probability $(0.01 \leq \mathrm{p}<0.05)$. Chlorophyll intake promotes stimulatory effects in the growth of tissue, promoting substance acting as a multiplication of fibroblasts, connective tissue cells, responsible for the healing process (Tanaka, 1997). Because of its high chlorophyll content, vegetables contribute to compose the daily intake.

When analyzed the total chlorophyll levels in lettuce leaves on the basis of the SPAD solutions as can be seen in Figure 2 that there was no statistically significant difference in chlorophyll levels for these solutions $\mathrm{S}_{2}=$ domestic wastewater; $\mathrm{S}_{3}=$ optimized domestic wastewater; $\mathrm{S}_{4}=$ well water; $\mathrm{S}_{6}=$ wastewater solution from the UASB reactor and $S_{7}=$ optimized wastewater solution from the UASB reactor whose means were 24.20, 22.60, 21.47, 21.67 and 22.72 respectively, but with a significant difference between $\mathrm{S}_{1}=$ solutions Furlani solution and $\mathrm{S}_{5}=$ optimized well water, whose averages were 19.15 and 16.52 respectively. Leonard et al. (2013) in his research is SPAD index is directly correlated with the chlorophyll content $(0.91)$ and the N content in the sheet (0.87), resulting in a positive correlation between both variables. Chlorophyll content in leaf D increases 0.0061 $\mathrm{mg} \mathrm{g}^{-1}$ as the index. 


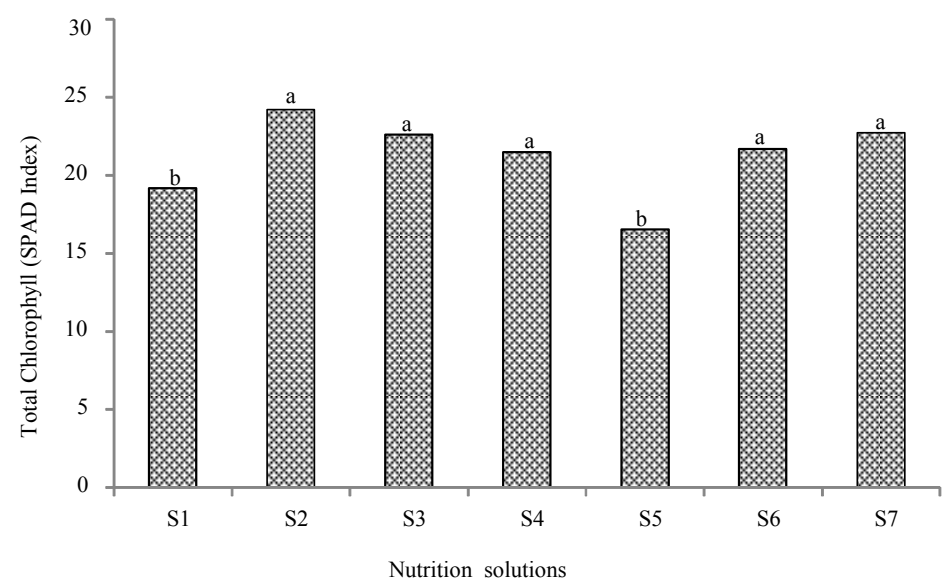

Figure 2. Indirect determination of chlorophyll levels in the leaves as a function of the solutions measured by SPAD index in the first experiment. $\mathrm{S}_{1}=$ Furlani solution; $\mathrm{S}_{2}=$ domestic wastewater (raw sewage); $\mathrm{S}_{3}=$ optimized domestic wastewater (raw sewage); $\mathrm{S}_{4}=$ well water saline; $\mathrm{S}_{5}=$ optimized well water saline; $\mathrm{S}_{6}=$ wastewater from the UASB reactor and $\mathrm{S}_{7}=$ optimized wastewater from the UASB reactor

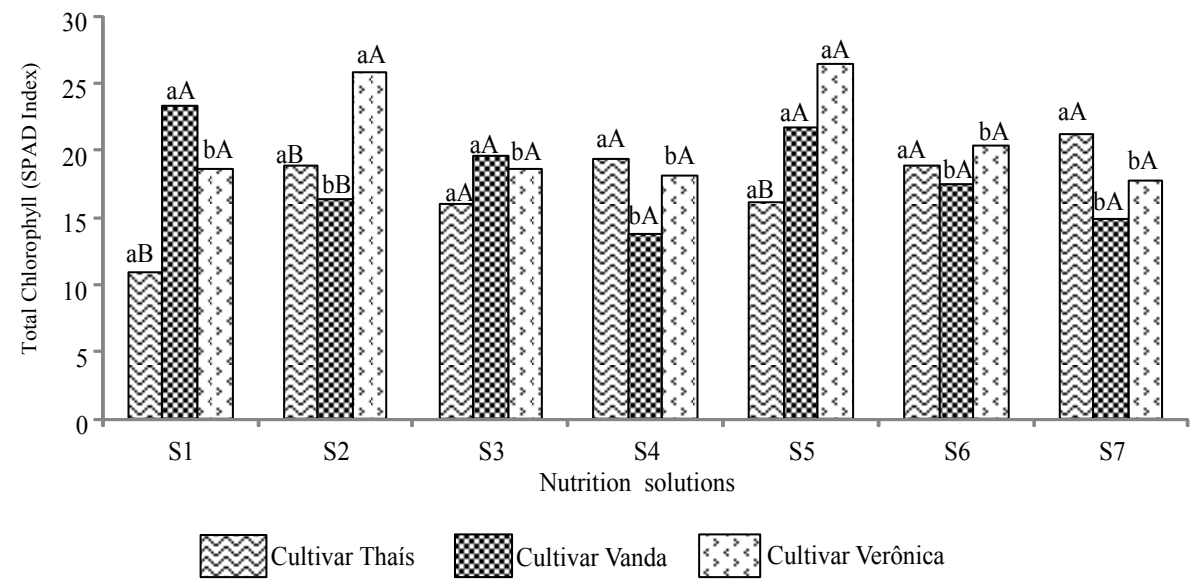

Figure 3. Indirect determination of chlorophyll levels in the leaves by the SPAD index versus scrolling cultivars (Thaís, Veronica and Vanda) solutions and the end of the second experiment. Means followed by the same letter do not differ solutions within the same cultivar and means followed by the same capital letter do not differ cultivars within the same solution. $\mathrm{S}_{1}=$ Furlani solution; $\mathrm{S}_{2}=$ domestic wastewater (raw sewage); $\mathrm{S}_{3}=$ optimized domestic wastewater (raw sewage); $\mathrm{S}_{4}=$ well water saline; $\mathrm{S}_{5}=$ optimized well water saline; $\mathrm{S}_{6}=$ wastewater from the UASB reactor and $\mathrm{S}_{7}=$ optimized wastewater from the UASB reactor

It appears that the major chlorophyll levels in the leaves measured by SPAD index for cultivating Thais were found when were used in irrigation the following solutions $S_{3}=$ optimized domestic wastewater, $S_{4}=$ well water $\mathrm{S}_{6}=$ wastewater solution from the UASB reactor and $\mathrm{S}_{7}=$ optimized wastewater from the UASB reactor solution whose average was 16.06, 19.33, 21.23 and 18.83, respectively. Looking at Figure 3 shows that the highest levels of chlorophyll in leaves measured by SPAD for the cultivar Vanda were found to grow when the solutions used were $\mathrm{S}_{1}=$ Furlani solution; $\mathrm{S}_{3}=$ Domestic wastewater, and $\mathrm{S}_{5}=$ optimized well water, whose averages were as follows $23.38,19.56$ and 21.75 , respectively. To the cultivar Verônica, the chlorophyll levels in the leaves measured by the SPAD index were observed with the solutions: $\mathrm{S}_{2}=$ domestic wastewater and $\mathrm{S}_{5}=$ optimized brackish well water where the averages were 25.58 and 26.43 respectively.

\section{Conclusions}

(1) Regardless of the nutrient solution, samples of Thaís cultivars, Vanda and Veronica analyzed showed no contamination by E. coli, meeting the standards set by the National Health Agency-ANVISA. 
(2) The use of nutritive mineral solutions using wastewater is feasible when used in hydroponic systems and is indicated mainly for the Brazilian semi-arid region and when it makes use of water of poor quality irrigation in vegetable production.

(3) In the first experiment, the total chlorophyll levels in lettuce leaves on the basis of the solutions by the SPAD index no differs statistically significant chlorophyll levels to the following $\mathrm{S}_{2}$ solutions, $\mathrm{S}_{3}, \mathrm{~S}_{4}, \mathrm{~S}_{6}$ and $\mathrm{S}_{7}$, but there was a significant difference between $\mathrm{S}_{1}$ and $\mathrm{S}_{5}$ solutions.

(4) In the second experiment, the SPAD index cultivars did not differ between when using the solutions $\mathrm{S}_{3}, \mathrm{~S}_{4}, \mathrm{~S}_{6}$ and $\mathrm{S}_{7}$. To cultivate Thaís, the SPAD index was statistically similar regardless of the solution used. With Vanda, the highest means were verified with the solutions $S_{1}, S_{3}$ and $S_{5}$ and with the cultivation of Veronica, the highest rates were observed with the SPAD were on $\mathrm{S}_{2}$ and $\mathrm{S}_{5}$ solutions.

\section{References}

Ayers, R. S., \& Westcot, D. W. (1999). A qualidade da água na agricultura (2nd ed.). Campina Grande: UFPB.

AOAC (Association of Official Analytical Chemists). (2002). Official methods of analysis of AOAC international (17th ed.). Washington, USA.

Arbos, K. A., Freitas, R. J. S., Stertz, S. C., \& Carvalho, L. A. (2010). Segurança alimentar de hortaliças orgânicas: Aspectos sanitários e nutricionais. Ciência e Tecnologia de Alimentos, 30(Supl. 1), $215-220$. https://doi.org/10.1590/S0101-20612010000500033

Argenta, G., Silva, P. R. F. da E., \& Bortolini, C. G. (2001). Teor de clorofila na folha como indicador do nível de N em cereais. Ciência Rural, 715-722.

Baumgartner, D., Sampaio, S. C., Silva, T. R. da, Teo C. R. P. A., \& Boas, M. A. V. (2007). Reuso de águas residuárias da piscicultura e da suinocultura na irrigação da cultura da alface. Engenharia Agrícola, 27(1), 152-163. https://doi.org/10.1590/S0100-69162007000100009

Bonini, M. A., Sato, L. M., Bastos, R. G., \& Souza, C. F. (2014). Alterações nos atributos químico e físicos de um Latossolo Vermelho irrigado com água residuária e vinhaça. Revista Biociências, 20, 56-63.

Brasil, Ministério da Agricultura. (1971). Equipe de Pedologia e Fertilidade do Solo. Divisão de agrologia-SUDENE. Levantamento exploratório (Boletim Técnico, 15, p. 670). Reconhecimento de Solos do Estado da Paraíba, Rio de Janeiro.

Brasil, Ministério da Saúde. (2001). Processamentos de Artigos e Superficies em Estabelecimentos de Saúde (2nd ed., p. 50). Coordenação de Controle de Infecção Hospitalar. Brasília.

CONAMA (Conselho Nacional do Meio Ambiente). (2005). Resolução No. 357. Diário Oficial da União. Retrieved from http://www.siam.mg.gov.br/sla/dow?idNorma=2747

Cova, A. M. W., Freitas, F. T. O. de, Viana, P. C., Rafael. M. R. S., Azevedo Neto, A. D. de, \& Soares, T. M. (2017). Content of inorganic solutes in lettuce grown with brackish water in different hydroponic systems. Revista Brasileira de Engenharia Agricola e Ambiental, 21(3), 150-155. https://doi.org/10.1590/1807-1929/ agriambi.v21n3p150-155

Costantin, B. D. S., Gelatti, L. C., \& Dos Santos, O. (2013). Avaliação da contaminação parasitológica em alfaces: Um estudo no sul do Brasil. Revista Fasem Ciências, 3(1), 1-14.

Dwyer, L. M., Anderson, A. M., \& Ma, B. L. (1995). Quantifying the nonlinearity in chlorophyll meter response to corn leaf nitrogen concentration. Canadian Journal of Plant Science, 75(1), 179-182. https://doi.org/ $10.4141 /$ cjps $95-030$

Ferreira D. F (2014). Sisvar: A Guide for its Bootstrap procedures in multiple comparisons. Ciênc Agrotec, 38, 109-112. https://doi.org/10.1590/S1413-70542014000200001

Furlani, P. R., Silveira L. C. P., Bolonhezi, D., \& Faquim, V. (1995). Cultivo hidropônico de plantas (Boletim Técnico, 180, p. 52). Campinas: IAC.

Itohan, A. M., Peters, O., \& Kolo, I. (2011). Bacterial contaminants of salad vegetables in Abuja Municipal Area Concil, Nigeria. Malaysian Journal of Microbiology, 7(2), 111-114.

Martínez, S., Suay, R., Moreno, J., \& Segura, M. L. (2013). Reuse of tertiary municipal wastewater effluent for irrigation of Cucumis melo L. Irrigation Science, 31, 661-672. https://doi.org/10.1007/s00271-012-0342-4

Minolta Co. Ltda. (1989). Manual for chlorophyll meter SPAD 502 (p. 22). Osaka, Minolta, Radiometric Instruments Divisions. 
Monteiro Filho, A. F. (2015). Análise técnica e econômica da alface crespa cultivada hidroponicamente com soluções minerais e organominerais otimizadas (p. 165, Tese de Doutorado, Universidade Federal de Campina Grande).

Oliveira A. B. A. (2005). Comparação de diferentes protocolos de higienização de alface (Lactua sativa L) utilizados em restaurantes de Porto alegre (65f, Dissertação Programa de Pós-graduação em Microbiologia Agrícola e do Ambiente, Universidade Federal Rio Grande do Sul, Porto Alegre).

Oliveira, P. G. C., Rodrigues, S. E. S., Almeida. C. G. L., Figueiredo, F. R., Rodrigues, F. F. G., Oliveira, A. D. L., \& Costa, J. G. M. (2010). Analises microbiológicas e parasitológicas de saladas verdes servidas em self-service no município de Crato-Ceará. Caderno de Cultura e Ciência, 2(2), 21-23.

Ramos, M. O., Begotti, I. L., Rosa, G., Vieira, G. F. P., Merlini, L. S., \& Messa, V. (2014). Avaliação parasitológica de alfaces (Lactuca sativa) comercializadas no município de Umuarama, Paraná, Brasil. Revista Brasileira de Higiene e Sanidade Animal, 8(3), 1-12.

Ribeiro, E. A., Sandri, D., \& Boêno, J. A. (2013). Qualidade da água de córrego em função do lançamento de efluente de abate de bovino. Revista Brasileira de Engenharia Agrícola e Ambiental, 17, 425-433. https://doi.org/10.1590/S1415-43662013000400011

Santos, A. N., Soares, T. M., Silva, E. F. F., Silva, D. J. R., \& Montenegro, A. A. A. (2010). Cultivo hidropônico de alface com água salobra subterrânea e rejeito da dessalinização em Ibimirim, PE. Revista Brasileira de Engenharia Agricola e Ambiental, 14, 961-969. https://doi.org/10.1590/S1415-43662010000900008

Santos, M. S. (2014). Risco microbiológico do consumo de saladas cruas e cozidas servidas em restaurantes self-service em Cruz das Almas, Bahia, e a eficiência da água sanitária na higienização das hortaliças (p. 95, Dissertação de Mestrado, Universidade Federal do Recôncavo da Bahia).

Schaer-Barbosa, M., Santos, M. E. P., \& Medeiros, Y. D. P. (2014). Viabilidade do reuso de água como elemento mitigador dos efeitos da seca no semiárido da Bahia. Revista Ambiente \& Sociedade, 17(2), 17-32. https://doi.org/10.1590/S1414-753X2014000200003

Tavella, L. B., Salino, A. J. S. da, Campos, P. A., Sebastião Neto, E. A., \& Ferreira, R. L. F. (2012). Aplicação foliar de produtos agroecológicos no desempenho agronômico da alface. Agropecuária Científica no Semiárido, 8(1), 23-27.

Tanaka, K., Yamada, A., Nada, K., Shoyama, Y., Kubo, C., \& Nomoto, K. (1997). Oral administration of a unicellular green algae, Chlorella vulgaris, prevents stress-induced ulcer. Plant Med., 63, 465-466. https://doi.org/10.1055/s-2006-957736

Tonet, A., Ribeiro, A. B., Bagatin, A. M., Quenehenn, A., \& Suzuki, C. C. L. F. (2011). Análise microbiológica da água e da alface (Lactuca sativa) cultivada em sistema aquapônico, hidropônico e em solo. Revista Brasileira de Pesquisa em Alimentos, 2(2), 83-88.

Varallo, A. C. T., Souza, J. M., Rezende, S. S. R., \& Souza, C. F. (2011). Avaliação da qualidade sanitária da alface (Lactuca sativa L.) irrigada com água de reuso comparada com amostras comercializadas. Revista Ambiente \& Água, 6, 295-304. https://doi.org/10.4136/ambi-agua.201

\section{Copyrights}

Copyright for this article is retained by the author(s), with first publication rights granted to the journal.

This is an open-access article distributed under the terms and conditions of the Creative Commons Attribution license (http://creativecommons.org/licenses/by/4.0/). 